(2)icimon

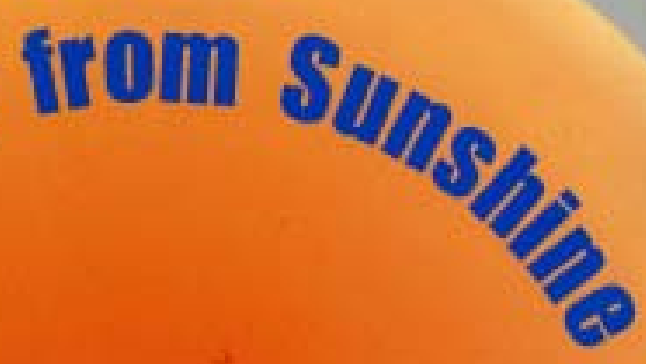

Passive Solar Building in the Mountains

Edited by

N. K. Bansal

Kamal Rijal

International Centre for Integrated Mountain Development Kathmandu, Nepal

2000 


\section{Profiting from Sunshine - Passive Solar Building in the Mountains}

N. K. Bansal

Kamal Rijal

Collection of Papers on National Workshops in China, India, Nepal and Pakistan 
Copyright (C) 2000

International Centre for Integrated Mountain Development All rights reserved

\section{Published by}

International Centre for Integrated Mountain Development G.P.O. Box 3226, Kathmandu, Nepal

ISBN 92-9115 -099-1

Editorial Team: Greta Mary Rana (Senior Editor) Dharma R. Maharjan (Technical Support and Layout Design) Asha K. Thaku (Cartography and Design)

\section{Typesetting at}

ICIMOD Publications' Unit

The views and interpretations in this paper are those of the author(s). They are not attributable to the International Centre for Integrated Mountain Development (ICIMOD) and do not imply the expression of any opinion concerning the legal status of any country, territory, city or area of its authorities, or concerning the delimitation of its frontiers or boundaries. 


\section{Foreword}

High altitude areas of the Hindu Kush-Himalayans are characterised by low ambient temperatures for most parts of the year. The inhabitants in this region rely on wood, agricultural residue, and animal waste to keep their houses warm, in particular during the winter season. The use of biomass has resulted in deforestation and ecological imbalances. Additionally the use of biomass for space heating without proper heating stoves severely affects the health of the occupants, especially women and children. There is therefore an urgent need to develop alternative options for space heating in the mountain areas of China, India, Nepal, and Pakistan.

ICIMOD, as an international institution committed to the development of mountain regions, recognised the need for appropriate design of buildings to help either to eliminate the use of fuels for space heating or reduce energy consumption. In order to have an overview of the available knowhow, technologies, and house building practices, ICIMOD supported the organization of national workshops on Passive Solar Building Technologies (PSBTs) in China, India, Nepal, and Pakistan. Prior to these workshops very little had been published on PSBT in the $\mathrm{HKH}$, and ICIMOD was requested to present the papers of all these workshops in a comprehensive and concise manner useful to the professionals engaged in promoting PSBTs. The present volume is an outcome of this effort. This document is the first of its kind to provide an overview on (i) Fundamentals of Solar Energy and Solar Radiation, (ii) State of the Art in Solar Passive Technologies, (iii) Solar Passive Building Design in the Mountains, (iv) Building Materials for Hilly and Mountain Areas, (v) Application and Design of Passive Solar Systems for Buildings, and (vi) Issues and Future Directions required for the promotion of PSBTs in the context of mountain areas of the HKH Region. I am confident that this document in its present form will be useful to those who are involved in the application and dissemination of passive solar building technologies. It also provides a good introduction to the subject for those energy specialists who are looking for new options for space heating in the $\mathrm{HKH}$.

I would like to extend my sincere appreciation to the programme coordinators from China, Mr. Wang Gehua, Director, Centre for Energy, Environmental Protection and Technology Development, Ministry of Agriculture, Beijing; to Dr. S.S. Chandel, Principal Scientific Officer, State Council for Science, Technology, and Environment, Shimla, India; to the Centre for Applied Research and Development and Department of Architecture, Institute of Engineering, Kathmandu; and to Aga Khan Housing Board for Pakistan, Karachi, for organizing the national workshops on Passive Solar Building Technologies in their respective countries and establishing a network of institutions on the subject in the HKH Region. 
I would like to thank Professor N.K. Bansal, Centre for Energy Studies, Indian Institute of Technology, New Delhi, for consenting to review the papers presented in the national workshops and to be one of the editors of this document.

Finally, I would like to thank Dr. Kamal Rijal, Renewable Energy Specialist, ICIMOD, who, as the Coordinator of the Programme, has been responsible for bringing out this document in its present form.

Mr. Egbert Pelinck

Director General

February 2000 


\section{Editorial Preface}

Although passive solar technology has been used by builders for three millennia and more (if one considers the techniques used in ancient Egypt and Mesopotamia), its applications in mountain regions are not as well documented as applications in other areas. For this reason we have not followed as strictly as is the norm the custom of listing only references cited. Whenever our authors have been able to give full particulars of a publication that can be used for buildings in mountain areas, it has been listed.

Readers will understand that passive solar technology in mountain areas has two dimensions;viz., the new applications that are being promoted on the market and the hidden part of the 'iceberg' as far as passive solar technology is concerned-the measures used traditionally to capture sunlight and profit from it. It is hoped that this document will enthuse researchers and builders to pursue this topic and search for all the applications possible that will make living and working in the mountains more comfortable in future than it has been in the past. 


\section{Abstract}

In the Hindu Kush-Himalyan (HKH) Region it is difficult to keep houses warm during winter. Usually biomass fuels are burned for cooking and space heating. Using biomass fuels has resulted in large-scale deforestation and ill effects on the health of mountain people, especially women and children, from the smoke produced. Solar radiation is available in most parts, and it is sensible to take solar energy consciously into consideration in designing buildings in order to reduce the use of biomass fuels for space heating.

The International Centre for Integrated Mountain Development (ICIMOD) is committed to improving the living standards of people living in the HKH Region. In the light of this objective, the Centre organized workshops on Passive Solar Building Technologies in China, India, Nepal, and Pakistan to establish a network of institutions involved in promoting Passive Solar Building Technology (PSBT) in mountain areas. The state-of-the art reviews clearly indicated that concrete efforts had been made in China and India to promote a solar passive heating programme, whereas there have been individual efforts in Nepal and Pakistan to build passive solar homes. The compilation of these papers in a comprehensive and concise manner should help to share knowledge about new developments in the respective countries as a means of promoting PSBTs in mountain areas.

This book, the first of its kind, provides an overview of the (i) National Workshops; (ii) Potentials for Application of PSBTs in Mountain Areas; (iii) Fundamentals of Solar Energy and Solar Radiation; (iv) State of the Art in Solar Passive Technologies; (v) Solar Passive Building Designs in the Mountains; (vi) Building Materials for Hilly and Mountain Areas; (vii) Application and Design of Passive Solar Systems for Buildings; and (viii) Issues and Future Directions required for the promotion of PSBTs in mountain areas of the Hindu Kush-Himalayan Region.

Overall, concrete solutions are needed to introduce solar passive building concepts in the HKH Region. Understanding climate, traditional architecture, construction materials, and construction techniques is important for optimum passive building designs, and this book attempts to provide some insights.

The following activities are recommended: (i) analysis and classification of climatic conditions in the HKH Region; (ii) study of vernacular architecture and identification of passive building elements; (iii) study of urban architecture; (iv) selection of an appropriate thermal simulation programme; (v) creation of a database and thermophysical properties of building materials and traditional building components; (vi) quantification of individual design patterns, for example, direct gain, indirect gain, thermal storage, solarium, cavity insulation, building form, roof shape, and underground structure; and (vii) preparation of manuals on design guidelines, design context, and construction issues. The information and knowledge thus prepared should then be disseminated to architects, users, and the construction industry, in both the formal and informal sectors. Design guidelines have not been provided for rural mountain areas anywhere in the world. Any initiative in this respect would help improve the health, efficiency, and lifestyles of rural people residing in mountain areas. 


\section{Acknowledgements}

The International Centre for Integrated Mountain Development (ICIMOD) recognised the need to review the status of passive solar building technologies (PSBT) in the $\mathrm{HKH}$ region and has made a conscious effort to disseminate knowledge of passive building science to these regions. The editors are grateful to the ICIMOD authorities for this initiative and for giving them the responsibility of editing the proceedings of four workshops. One of the editors (N.K. Bansal) is personally grateful to Dr Kamal Rijal, the joint editor, for asking him to co-edit the work. Editing was not simple and the help of Dr. M. S. Bhandari of IIT Delhi is acknowledged for his help in collating the written texts. 


\section{Acronyms}
Ah Ampere hour
ASHRAE Association of Heating, Refrigeration and Air-Conditioning Engineers
BTU British Thermal Unit

CBRI Central Building Research Institute

COP Coefficient of Performance

CPWD Central Public Works Department

CSIR Council of Scientific and Industrial Research

DD Degree Day

DDC Direct Digital Control

EJ Eta Joule

EMSs Energy Management Systems

FET Fluorinate Ethylene Teraphithlate

FLC Fuzzy Logic Controller

GI Galvanised Iron

HKH Hindu Kush-Himalayas

HP Himachal Pradesh

HVAC Heating, Ventillation and Air-Conditioning

ICIMOD International Centre for Integrated Mountain Development

ICS Improved Cooking Stove

IFA International Energy Agency

IIT Indian Institute of Technology

IR Infrared

ITBP Indian Tibet Border Post

J Joule

KJ Kilo Joule

${ }^{\circ} \mathbf{k} \quad$ degree kelvin

kWh kilowatt hour

masl metres above sea level

MIT Massachussets' Institute of Technology

MJ Million Joule

mm milimetre 
NBRI National Building Research Institute

NGO Non-Governmental Organization

NIST National Institute of Silicon Technology

PCM Polycrystalline membrane

PMA Polymethylacrylate

PSBT(s) Passive Solar Building Technology

Pv Photovoltaic

R\&D Research and Development

RBC Reinforced Brick Concrete

RC Reinforced Concrete

RCC Reinforced Cement Concrete

SHS Solar Home System

SIER Shanghai Institute of Energy Research

TAP Thermosiphonic Air Panel

tce tonnnes of coal equivalent

TI Transparent Insulation

TIM(s) Transparent Insulation Material(s)

UNDP United Nations Development Programme

UP Uttar Pradesh

UV Ultra-violet

U-Value thermal insulation

V Volt 


\section{Contents}

Chapter 1: Summary and Synthesis of National Workshops

Introduction

Synthesis

Chapter 2: Passive Solar Building Technology: Potentials for Application in Mountain Areas

Background

The Context

Historical Perspective

Passive Solar Building Technology: What Is It?

Availability of Solar Energy in the HKH Region

Potentials for Application to Meet Demands for Heating

Principles of Passive Solar Building Design for Cold Climates

Issues in Solar Passive Building Technologies

Concluding Remarks

Chapter 3: Fundamentals of Solar Energy and Solar Radiation

Fundamentals of Solar Energy

Climatology and Passive Solar Building

The Spectral Characteristics of Global Radiation and Surface Albedo on the Northern Tibetan Plateau

Direct and Global Solar Radiation in the Region of Mt. Qomolangma

During the Summer of 1992

Chapter 4: State of the Art in Passive Solar Technologies

International Status of Solar Passive and Low Energy Building

Technologies for Cold Climates

Development of Passive Solar Building in China

Solar Building in Tibet

Passive Solar Building Construction at High Latitudes 
Passive Solar Building Technologies for the Hindu Kush and the Himalayan Region (HKH)

Natural Cooling, Heat Insulation and Improved Wall Materials for Solar Buildings

Automated Controls and Photovoltaics in Solar Passive Building

Chapter 5: Passive Solar Design of Buildings in the Mountains 117

A Review of Various Techniques for Passive Solar Building

Thermal Simulation for Energy Conservation: Case Studies of CPWD Buildings in High Altitude Regions

Survey and Design Studies on Residential and Dispensary Buildings in Hilly Regions

Research on the Regional Advantages of Passive Solar Buildings in High and Cold Areas in Yunnan Province

Energy Efficient Building Design: Passive Solar Energy Approach

Retrofitting Traditional Buildings by Passive Solar Concepts in Jumla and Solukhumbu

Analysis Before and After Incorporation of Passive Solar Building Technology in Buildings in the Himalayan Region

Studying Indoor Thermal Comfort and Solar Energy Resources in the Northern Areas of Pakistan

Chapter 6: Building Materials for Hilly and Mountain Areas

Recent Developments in Materials for Solar Buildings

Solar Heating of Buildings in Hilly Areas Using TIMs

Appropriate Design, Construction Techniques and

Building Materials for Thermal Efficiency of Buildings

Focus on Heat Pumps and Heat Pipes

\section{Chapter 7: Application and Design of Pasive Solar}

\section{Systems for Buildings}

Solar Design for Hilly Areas: Proposed Hypocaust System for Indira Gandhi Hospital, Shimla

Design of a Solar Heating System for a House in a Model Village in the Hindu Kush and Himalayan Range

Energy Efficient and Environmentally Sustainable Designing of School Building in Northern Areas Pakistan 
Standard Low cost Urgan housing in Metroville - 1, Karachi Guidelines for Improving Thermal Comfort in Existing Houses

Chapter 8: Issues and Future Directions

Chapter 9: Appendix-Climatic Parameters in the HKH Region 273

Chapter 10: Index of Keywords and Phrases 